Review

\title{
Awareness of surgical smoke hazards and enhancement of surgical smoke prevention among the gynecologists
}

\author{
Yi Liu, Yizuo Song, Xiaoli Hu, Linzhi Yan, Xueqiong Zhu ${ }^{\bowtie}$ \\ Department of obstetrics and gynecology, the Second Affiliated Hospital of Wenzhou Medical University, Wenzhou, China \\ $\triangle$ Corresponding author: Xueqiong Zhu, Department of Obstetrics and Gynecology, the Second Affiliated Hospital of Wenzhou Medical University, Wenzhou \\ 325027, China. Email: zjwzzxq@163.com. Phone number: 08613906640759. ORCID: 0000-0002-8389-928X \\ (C) Ivyspring International Publisher. This is an open access article distributed under the terms of the Creative Commons Attribution (CC BY-NC) license \\ (https://creativecommons.org/licenses/by-nc/4.0/). See http://ivyspring.com/terms for full terms and conditions.
}

Received: 2018.11.13; Accepted: 2019.04.29; Published: 2019.06.02

\begin{abstract}
Surgical smoke is the gaseous by-product produced by heat generating devices in various surgical operations including laser conization and loop electrosurgical procedures that often are performed by gynecologists. Surgical smoke contains chemicals, blood and tissue particles, bacteria, and viruses, which has been shown to exhibit potential risks for surgeons, nurses, anesthesiologists, and technicians in the operation room due to long term exposure of smoke. In this review, we describe the detailed information of the components of surgical smoke. Moreover, we highlight the effects of surgical smoke on carcinogenesis, mutagenesis, and infection in gynecologists. Furthermore, we discussed how to prevent the surgical smoke via using high-filtration masks and smoke evacuation systems as well as legal guidelines for protection measures among the gynecologists.
\end{abstract}

Key words: Cervical cancer; Cervical intraepithelial neoplasia; Electrosurgery; Smoke; Gynecologist.

\section{Introduction}

Cervical cancer remains to be one of the leading causes of cancer-related death in women despite advances in screening, diagnosis, prevention, and treatment. An estimated 13,240 patients will be diagnosed with cervical cancer in the United States in 2018 and about 4,170 cases will die because of this deadly disease, corresponding to almost 11 deaths per day [1]. Therefore, to obtain the better treatment outcomes, the prevention is imperative via early detection of precancerous and high-grade cervical intraepithelial neoplasia (known as cervical dysplasia, CINII and CINIII), which is the potentially premalignant transformation and abnormal growth (dysplasia) of squamous cells on the surface of the cervix [2-4]. Emerging evidence has demonstrated that virus infection and multiple molecular signaling pathways were critically involved in cervical tumorigenesis. Studies have revealed that human papillomavirus (HPV) infection is associated with progression of CINII and CINIII, and invasive cancer. Especially, patients with infection of HPV strains 16 and 18 cause about $70 \%$ of CINII, CINIII, and cervical cancer $[3,5,6]$. Thus, HPV vaccine is useful for prevention of the cervical cancer.

The treatment of CIN is effective and safe $[7,8]$. The cervix lesions need to be treated with an ablative approach or an excisional technique, which are dependent on the size and location of the lesion [9]. The ablative approaches have cryotherapy and thermal ablation, while excisional methods have large loop excision or cold knife conization. Currently, the treatment for CIN applies for laser and electrosurgical managements. Laser conization and electrosurgical procedures such as the loop electrosurgical excisional procedure (LEEP) have been considered as accurate techniques in cervical cancer prevention [9-11].

To date, using electrocautery and lasers by gynecologists in cervical cancer and ovarian cancer is frequent, especially LEEP treated for CINII and CINIII with HPV infection, which may cause a critical healthy problem due to gaseous byproducts or "surgical smoke" produced by these devices. Surgical smoke poses a wealth of potential risks to the gynecologists, including the direct physical injury, 
mutagenicity and transmission of infectious diseases especially HPV. However, legal guidelines and standardized recommendations within the gynecologists have not yet been established. Thus, in the following sections, we will review the contents and potential risks of surgical smoke and offer some recommendations for gynecologists to minimize the hazards.

\section{What is the surgical smoke?}

Surgical smoke is the gaseous by-product produced when tissue is dissected or cauterized by heat generating devices such as lasers, electrosurgical units, ultrasonic devices, and high speed burrs, drills and saws. Among these devices, the most common sources are electrocautery ablation and laser ablation $[12,13]$. During the surgical procedures, the heat of a diathermy causes the target cell membranes to rupture to its boiling point, and subsequently generates a plume of smoke containing mostly water vapor and then releases into the atmosphere of the operating room $[13,14]$. At the same time, the intense heat created by chars protein and other organic matter within the cells causes thermal necrosis in the adjacent cells. The charring of cells also releases other harmful contaminants, such as carbonized cell fragments and gaseous hydrocarbons [15].

Surgical smoke, the encompassing term for a number of gaseous byproducts produced by energy-based surgical instruments, is also known as plume, aerosols, smoke, cautery smoke, diathermy plume and smoke plume [14, 16-18]. Most of these terms are often used interchangeably. However, the term "smoke", although it is not formally correct in all cases, is used to describe this surgically generated gaseous by-product [18].

\section{The risks of surgical smoke}

There are many disadvantages of surgical smoke, such as hindering the vision of the surgeon, producing an unpleasant odor, and releasing hazardous chemicals that include mutagens and carcinogens into the environment of operating room $[19,20]$. A current study that was carried out in the operating rooms with 45 nurses and 36 doctors demonstrated that all of the 81 nurses and doctors exposed to surgical smoke experienced headaches, watery eyes, coughs, burning throats, nausea, bad odors absorbed in the hair, drowsiness, dizziness, sneezing and rhinitis [21]. In addition to the harmful chemicals, surgical smoke has been demonstrated to harbor contagious, viable malignant cells, and even to contain live bacteria and viruses, including HPV and human immunodeficiency virus [22-24], all of which may induce great damage to the persons in the operation rooms. For example, $80 \%$ smoke plumes were found to be positive for HPV from patients with HPV-positive CIN after LEEP treatment, suggesting that stringent control procedures could be required to protect gynecologist [23]. Each year, in America, a total of approximately 500,000 personnel including surgeons, nurses, anesthesiologists, and technicians were exposed to surgical smoke in the operating rooms, and these exposures were cumulative over their lifetimes [25]. Even though surgical smoke is not an immediate health hazard, operating room personnel should be aware of the potential long-term health risks.

\section{The components of surgical smoke}

\section{Chemical compositions and hazards}

Surgical smoke is made up of $95 \%$ water or steam and 5\% cellular debris in the form of particulate material which is composed of chemicals, blood and tissue particles, viruses, and bacteria $[17,26]$. As the studies revealed, the size of the particulate matter is decided by the device used and tissue type [26]. Electrocautery creates particles with the smallest mean aerodynamic size $(0.07 \mu \mathrm{m})$, whereas laser tissue ablation creates larger particles $(0.31 \mu \mathrm{m})[27,28]$. On the other hand, Karjalainen et al. [29] compared the deposition of particulate matter in ten different tissues containing skeletal muscle, liver, lung, bronchus, subcutaneous fat, renal pelvis, renal cortex, cerebral gray and white matter, and skin, all taken from the porcine tissues. The results showed that liver produced the highest number of particles, skeletal muscle and renal tissues produced a medium mass of particulate matter, while other tissues produced significantly less particulate mass, firmly suggesting the obvious differences in particle production of the surgical smoke depending on the electrocauterized tissue types [29].

There are mounting evidences suggesting that particles about $5 \mu \mathrm{m}$ or larger are deposited on the walls of the nose, pharynx, trachea, and bronchus, while those smaller than 2 micrometers are deposited in the bronchioles and alveoli [26-28]. Besides, 77\% of particles inside the plume are less than $1.1 \mu \mathrm{m}$ with a mean diameter of $0.07 \mu \mathrm{m}[30,31]$, and a mean diameter of $0.22 \mu \mathrm{m}$ to $0.056 \mu \mathrm{m}$ are certainly in the inspirable range [17]. Therefore, smoke may induce acute and chronic inflammatory changes, including alveolar congestion, interstitial pneumonia, bronchiolitis, and emphysematous changes in the respiratory tract $[18,28]$. Baggish et al. [32, 33] reported that laser-produced surgical smoke was harmful to the lungs of rat models. In the study, it was observed that the inhalation of surgical smoke caused 
amount of damage from inflammatory interstitial pneumonia to extensive emphysema and that the changes proportionally increased with extended exposure. Moreover, Gates et al. [34] also reported that long-term exposure to surgical smoke, as measured by the duration of operating room employment, appears to increase the risk of chronic pulmonary conditions other than lung cancer, such as asthma or pneumonia. Another survey by Ball et al. [35] found that, compared to the general population, perioperative nurses displayed twice the incidence of some respiratory problems such as sinus problems, infections and bronchitis. Although the study did not discover any correlation between the inhalation of surgical smoke and respiratory problems, these findings could be a wake-up call for concern, as these conditions have been linked to inhaling surgical smoke.

In vitro investigation has identified many chemicals in the surgical smoke plume [12]. So far, researchers have identified more than 80 chemical compounds in the surgical smoke [36]. The most abundant chemicals in electrocautery smoke are hydrocarbons, nitriles, fatty acids and phenols. The plumes generated by laser tissue ablation include benzene, formaldehyde, acrolein and polycyclic aromatic hydrocarbons [28]. In addition, surgical smoke from adipose tissue produces more aldehydes than ketones whereas epidermal tissue ablation creates more toluene, ethyl benzene, and xylene [37]. Similar to this concept, another elegant study identified 9 main carcinogenic chemical compounds in surgical smoke form porcine tissues, butadiene, benzene and furfural was demonstrated to be obviously exceeded permissible exposure [38]. Further analyses revealed that as compared to muscle tissue, liver tissue of porcine contributed to higher concentrations of butadiene, benzene and furfural when cauterized in electrosurgery [38]. Chung et al. [20] collected 12 smoke samples from a continuous irrigation suction drainage system during TURP (transurethral resection of the prostate) and vaporization. This study showed that there were 16 main chemical constituents of surgical smoke including propylene, allene, isobutylene, 1,3-butadiene, vinyl acetylene, mecaptomethane, ethyl acetylene, diacetylene, 1-pentene, ethyl alcohol, piperylene, propenylacetylene, 1,4-pentadiene, cyclopentadiene, acrylonitrile and butyrolactone. Moreover, a recent study conducted by Sisler et al. [39] collected 36 surgical smoke samples by using an electrocautery surgical device to cut human breast tissues and characterized the particles from plumes. They detected 17 different volatile organic compounds in all the 36 surgical smoke samples, and high concentrations of acetaldehyde, ethanol and isopropyl alcohol were detected in every sample predominantly.

Acrylonitrile, is a colorless and volatile chemical that is able to be absorbed through the skin and lungs and exerts its toxicity by liberating cyanide [27]. The exposure levels of operating room personnel to acrylonitrile have been demonstrated to be 1.0-1.6 parts per million (ppm) [40]. Short-term exposure to acrylonitrile can cause eye irritation, nausea, vomiting, headache, sneezing, weakness and lightheadedness, whereas long-term exposure causes cancers in laboratory animals and has linked to higher incidences of cancer in humans. Repeated or prolonged exposure of the skin to acrylonitrile may produce irritation and dermatitis [28].

Hydrogen cyanide, which is liberated by acrylonitrile, is also a toxic colorless gas that can be absorbed into the lungs through the skin and the gastrointestinal tract [17]. Excessive exposure to hydrogen cyanide can cause cardiac arrhythmias, dyspnea, coma and even death, while chronic low level exposure may result in neurological effects such us headache, vertigo, nausea, and vomiting [15, 27]. Therefore, the United States Department of Health and Human Services has set the short-term exposure limit of hydrogen cyanide at $10 \mathrm{ppm}$ [40].

Benzene has been detected at high levels (71 $\left.\mu \mathrm{g} / \mathrm{m}^{3}\right)$ near the electrocautery pencil during colorectal surgery and in the ambient air of the operating room $\left(0.5-7.4 \mathrm{mg} / \mathrm{m}^{3}\right)$ [39]. In epidemiological study, clinical and laboratory data linked benzene exposure to aplastic anemia, acute leukemia, and bone marrow abnormalities [25-27, 42]. As stated by Occupational and Safety Health Administration (OSHA) [26], the short-term effects of benzene include headache, dizziness, nausea, and irritation of the eyes, nose, and respiratory tracts. National Institute of Occupational Safety and Health $(\mathrm{NIOSH})$ recommended that exposure limit of benzene is $0.1 \mathrm{mg} / \mathrm{m}^{3}$ and the OSHA limit of benzene is $0.2 \mathrm{mg} / \mathrm{m}^{3}$.

\section{Carcinogens in surgical smoke}

Among these chemical compounds existing in surgical plume, acetaldehyde, acrolein, acrylonitrile, benzene, cyclohexanone, formaldehyde, furfural, polyaromatic hydrocarbons, styrene, toluene and xylene have been classified as carcinogens by the IARC (International Agency for Research on Cancer) [43]. 1,3-butadiene, vinyl acetylene and acrylonitrile have been demonstrated to be very toxic and carcinogenic further [20]. One study by Oganesyan et al. [44] used a well-established method to collect the smoke during active electrosurgery placed at 16 to 18 
inches above the cautery point. The results showed the high concentrations of known carcinogens in surgical smoke such as benzene, butadiene, and acetonitrile. In addition, butadiene and benzene showed 17- and 10-fold higher concentration than second-hand smoking, respectively, which have been reported to cause acute or delayed toxicity and have potential carcinogenic effects on humans.

Laboratory and animal studies have demonstrated that smoke generated during laser and electrocautery surgery causes acute or delayed carcinogenic effects on humans. Even though there is no direct evidence to show that surgical smoke is carcinogenic to humans, there are persistent concerns.

\section{Mutagenic potential of surgical smoke}

As well as chemical components, the mutagenicity and cytotoxicity were of greatest concern to users of lasers, electrosurgery, and powered surgical instruments. Tomita and colleagues collected the electrosurgery smoke particles generated from mucous membrane of the canine tongue irradiated with a $\mathrm{CO}_{2}$ laser, and found that condensates of surgical smoke have mutagenicity on TA98 in the presence of S9 mix, and $\mathrm{His}^{+}$revertants were induced with an increased dose of the condensates [45]. This result demonstrated the mutagenicity of a TA98 strain of Salmonella. Moreover, the authors quantified the mutagenic effect created by thermal destruction of $1 \mathrm{~g}$ of tissue was equivalent to that of three to six cigarettes respectively. Then, Gatti et al. [46] used the standard Salmonella microsomal test, an established technique for evaluating the mutagenicity of a substance, to assess the mutagenic potential of the electrocautery-derived smoke created during the reduction mammoplazy, and found the mutagenicity of smoke to a TA98 strain of Salmonella. In a subsequent laboratory study with porcine liver tissue repeatedly cutting by electro-surgical hook knife, authors collected the plumes and observed that the clonogenicity of the MCF-7 human breast carcinoma cells decreased about 30\% when exposed to this plumes, suggesting the cytotoxicity of electro-surgical smoke [47, 48]. Additionally, an in vitro experiment has discovered that surgical smoke from human breast tissues via electrocautery surgical device induced cytotoxicity in human small airway epithelial cells and mouse macrophages [39], implying that surgical smoke may be an occupational hazard to healthcare workers. It was not determined in either study whether the plumes actually posed a serious health risk to perioperative personnel, but more attention should be paid for surgeon to safe levels of ambient mutagens.

\section{Biological components of surgical smoke}

\section{Viable malignant cells}

In addition to the various chemical compositions, surgical smoke also contains transmissible, viable malignant cells. As early as 1999, Fletcher et al. [24] cauterized pellets of B16-F0 mouse melanoma cells to collect plums and assessed cell viability by the way of the trypan blue assay and the tetrazolium viability assay, which showed that viable melanoma cells were present in the culture wells. These results demonstrated that plumes of electrocautery contained malignant cells which was viable and may explain the appearance of port-site metastases that were remoted from the surgical dissection or never in direct contact with the tumor. Another study also assessed the ability of surgical smoke to spread aerosolize malignant cells by the way of collecting thirty-five patients undergoing elective laparoscopy. As a result, aerosolized mesothelial cells were identified only in two patients, but one patient who displayed cellular aerosolization developed a port-site recurrence after following-up 2 to 7 months [49]. In the same year, other researchers collected surgical plume with Transwell membrane from various tumour cell lines (NCI-H292, FaDu, KB, AGS, ARO) cauterized by electrocautery, radiofrequency ablation and ultrasonic scalpels. These experiments demonstrated that it was only from the ultrasonic scalpel, but not from the electrosurgical unit or radiofrequency ablation device that viable cells were identified in all 25 smoke samples retrieved from a distance of $5 \mathrm{~cm}$ [50]. However, no more study has demonstrated the transmission of cancer cells to operation room personnel during electrosurgery [31].

\section{Viable bacteria}

A study by Schultz et al. [51] has demonstrated the extent of viable bacteria present in surgical plume with an experimental model of porcine tissue embedded with Serratia marcescens, which transmitted directly to operation room personnel. The researchers concluded that it was the blended current electrosurgery rather than pure coagulation electrosurgery that transmitted bacteria to nearby or adjacent sites.

\section{Virus and its infection in gynecologist}

\section{HPV was detected in surgical smoke}

The first insights into the infection of surgical smoke were those numerous animal and human studies about the viruses in the smoke to date. Several articles stated that HPV was not found in the plume, and others demonstrated that the risk of HPV contamination was low or impossible for the operation room staff $[52,53]$. Weyandt at el. [52] 
collected petri dishes placed in 1 and $2 \mathrm{~m}$ distance to the treatment weld and swabs from the glasses and nasolabial folds of the operating physician to assess the generation of aerosols containing HPV DNA during treatment of genital warts with multilayer argon plasma coagulation and with $\mathrm{CO}_{2}$ laser ablation. They confirmed that HPV types of genital warts were not found in any of the petri dishes and swabs obtained during this treatment. Despite of the ability to transmit HPV DNA in surgical plume, the risk of dispersal of HPV to surgeons and the development of clinically active infection appears to be low [53].

However, the risk of occupational human papillomavirus transmission from patient to medical personnel during laser vaporization procedures remains controversial. As early as 1988, in order to analyze the viral DNA content in the vapor produced by the carbon dioxide laser during the vaporization of papillomavirus-infected verrucae, Garden et al. [54] used two models for evaluation: an in vitro cutaneous bovine fibropapilloma and an in vivo human plantar or mosaic verruca model, both of which demonstrated that intact viral DNA was in the plume collected during carbon dioxide laser therapy of papilloma virus-infected verrucae. Next year, Sawchuk et al. [55] also used a bioassay to demonstrate the presence of human papillomavirus DNA in surgical smoke derived from human plantar warts treated with carbon dioxide laser and electrocoagulation. In a subsequent study, Garden and colleagues went on to collect the laser plume from bovine papillomavirus-induced cutaneous fibropapillomas and then reinoculated onto the skin of calves. The results revealed that substantial amounts of bovine papillomavirus DNA were present in all of the laser plume samples and tumors developed in all of 3 calves in sites of control bovine papillomavirus (BPV) concentrate inoculums were infected with the same virus type, confirming that bovine papillomavirus isolated from carbon dioxide laser plume did induce lesions in healthy animals [56]. Later, many studies have demonstrated the presence of HPV in the plume. Sood et al. [23] conducted a study of 49 patients with evidence of CIN undergoing loop electrosurgical excision procedures. In the study, 39 plume samples were reported to be positive for HPV, with $16 / 18$ most, which showed that the plume of smoke generated by LEEP had HPV DNA. Furthermore, according to a study including patient tissue samples from the urethral warts $(n=5)$, laryngeal papilloma (n =5) which were all found positive for HPV, and the surgical gloves $(n=20)$ used by the employees such as the physicians and nurses. The results showed that all samples obtained from the surgical gloves tested positive for HPV after urethral warts procedures, and in one of the five surgeons and in three of the five nurse tested HPV positive after the treatment of laryngeal papilloma, respectively. Interestingly, all HPV genotypes presented were identical to the HPV of corresponding patient tissue specimens [57]. A relatively recent study evaluated HPV subtypes between the resected cones of LEEPs and the surgical plume resulting from LEEPs of high-grade squamous intraepithelial lesion of the cervix uteri and surprisingly found that these plumes contained high-risk HPV which was consistent with HPV subtypes identified in the resected cones. The further investigations of contamination with surgical plume are necessary for evaluation of potential hazards to be involved in gynecologists [58].

The infection of HPV found in gynecologist due to surgical smoke

Although the possibility of disease transmission through surgical smoke exists in humans, actual documented cases of pathogen transmission are rare. Four cases have essentially been proven. A 44-year-old gynecological laser surgeon, who had no respiratory diseases and was healthy, developed laryngeal papillomatosis and infected with HPV types 6 and 11 after treating patients with anogenital condylomata known to harbor the same viral types [59]. In Germany, a 28-year-old gynecological operating room nurse, who assisted repeatedly in electrosurgical and laser surgery in excisions of anogenital condylomas, developed a recurrent and histologically proven laryngeal papillomatosis. The expert opinion of a virological institute confirmed a high probability of correlation between the occupational exposure and the laryngeal papillomatosis [60]. A 53-year-old male gynecologist who have performed laser ablations and LEEP on greater than 3000 dysplastic cervical and vulvar lesions over 20 years of practice, presented with HPV 16 positive tonsillar squamous cell carcinoma. However, he had no identifiable risk factors other than long term occupational exposure to laser plumes. Another patient was a 62-year-old male gynecologist with a 30 year history of laser ablation and LEEP, having very few other risk factors for oropharyngeal cancer or HPV infection, subsequently developed HPV 16 positive base of tongue cancer [61]. Due to that HPV could induce inflammation and carcinoma, protective measures should be instituted for all healthcare personnel, particularly gynecological surgeons [62].

\section{Other virus in surgical smoke}

In addition to HPV, human immunodeficiency virus (HIV) is also receiving a lot of attention because 
of its increasingly prevalence in the general population. Baggish et al. [22] conducted a research in which HIV proviral DNA was captured in the inner lumen of smoke evacuation tubing after in vitro laser vaporization of cultured HIV cells. This study has clearly shown that HIV was present in the laser smoke. Furthermore, Taravella et al. [63] found that infectious polio virus could be propagated in the plume collected from oral polio virus infected fibroblasts by means of an excimer laser. The evidence of a recent study revealed that hepatitis B virus (HBV) was present in surgical smoke. Kwak et al. [64] collected surgical smoke from 11 patients undergoing laparoscopic or robotic surgery. In sequence of HBV gene amplification and DNA sequencing, the authors found that HBV was detected in 10 of the 11 samples of surgical smoke.

\section{Protective measures for gynecologist}

\section{Mask: an effective protector}

After completing a search of the literature, all articles in this literature synthesis identified personal respiratory protection to prevent surgical smoke inhalation injury, such as a basic surgical mask, high-filtration mask, or an N95 respirator [65]. Surgical masks, in general, providing more than $90 \%$ protection for the patient and the operating room staff from exposure to surgical smoke, have been in use for more than a century [66]. Today, the focus of protection has shifted to how surgical masks can be used as a safeguard for the surgical staff from surgical smoke.

In one report of Sawchuk et al. [55], the authors conducted repeat experiments analyzed by dot-blot hybridization to identify whether placing a surgical mask in the vapor path could inhibit the papillomavirus in surgical plume. The results showed that no viral DNA was detected from vapor after placing a mask and abundant viral DNA was extracted in this mask, which strongly suggested that the potential risk of surgical smoke inhalation might be markedly reduced by wearing a surgical mask. Lewin et al. [26] also suggested that high-filtration masks should be used to prevent exposure in surgical smoke. However, the conclusion of the research by Oberg et al. [67] indicated that none of these surgical masks exhibited adequate filter performance can be considered respiratory protection devices. In this research, filtration performance was evaluated by means of monodisperse latex sphere and sodium chloride aerosols, and facial fit of surgical smoke was evaluated by qualitative and quantitative fit tests. As a result, all 9 masks exhibited a wide range of particle penetration both in latex sphere challenge tests
(0\%-84\%) and sodium chloride challenge tests (4\%-90\%), respectively. Another assay described that live, infectious virus was extracted from the plumes behind all surgical masks tested, suggesting that influenza virus surviving in aerosol particles could be able to bypass or penetrate a surgical mask [68]. Besides, to be effective, respirator filtering materials must allow only minimal penetration of the contaminant and provide an airtight faceseal or positive pressure inside the facepiece. However, traditional surgical masks fulfill neither of these requirements. Their vulnerability of penetration demonstrated that surgical masks offered only partial protection because they filtered out particulates only as small as $5 \mu \mathrm{m}$ in diameter, by the way when sizes smaller than $5 \mu \mathrm{m}$, these particles were not filtered by surgical masks and might be inhaled by personnel in the operation room [31]. In addition, even high-filtration masks also referred to as laser masks, whose filter particles are about 0.1 micrometers in size $[65,69]$. Actually, the particulate size of the particles in the smoke has been documented to be much smaller than $5 \mu \mathrm{m}$ particulate diameter that standard surgical masks could filter [17]. Bacteria can be as large as $30 \mu \mathrm{m}$ or smaller as $0.3 \mu \mathrm{m}$, and viruses are smaller and can range in size from $0.01 \mu \mathrm{m}$ to $0.3 \mu \mathrm{m}$. Besides, it has been reported that small particles less than $1.1 \mu \mathrm{m}$ in diameter constitute $77 \%$ of the particulate matter found in surgical plume [69]. As a result, most surgical masks do not have adequate filtering or fitting attributes to provide respiratory protection for wearers.

Some current-model surgical masks such as Health Care Particulate Respirators categorized into $\mathrm{N}, \mathrm{R}$ and $\mathrm{P}$ classes have greater filtering and face seal capabilities, and the most commonly used are N95 and other NIOSH-approved respirators [70]. Emerging evidence has illustrated the high efficiency particulate air (HEPA) filters are capable to arrest fine particles effectively, such as N95 respirator masks [71], which have the filter efficiency over $95 \%$ when challenged with $0.3 \mu \mathrm{m}$ aerosols. Although no guidelines on the use of respirators for surgical procedures, it seems that respirators that are at least N95 grade provide the best protection against surgical smoke produced during the use of electrocautery, lasers, or ultrasonic scalpels. In the study of Edwards et al. [72], suggested that the key respiratory protection was the use of N95 and other $\mathrm{NIOSH}$-approved respirators, because it was the only respiratory protection choice proven effective for personnel protection. Another research by Gao et al. [73] calculated the total protection factor to measure the performance of common surgical masks, N95 and N100 which were exposed to the surgical smoke 
collected from surgical dissections on animal tissue by standard electro-cautery device. The results of this study revealed that the total protection factor of common surgical masks was close to 1 which provided minimal protection against surgical smoke, while the total protection factor of N95 surgical mask respirator was 208-263 and N100 filtering face piece respirator was 1,089-2,199, which could offer a higher level of protection. Notably, an elegant study compared the filtration efficiency of airborne bacteria between N95 respirator and disposable surgical mask, as a result, the filtration efficiency of N95 and disposable surgical mask were $99.93 \%$ and $91.53 \%$, respectively, demonstrating the significant difference between the two masks [74]. Consistent with these findings were data showing that N95 respirators provided more protection in case of clinical respiratory illness and laboratory-confirmed bacterial, suggesting the effective use of respiratory protection for healthcare workers [75].

On the contrary, some researchers found that it was very difficult to breathe with an N95 mask because $\mathrm{CO}_{2}$ levels elevated significantly, and it was easy to have some subjective symptoms, the complaints of headache, lightheadedness, and difficulty in communication [76]. Compared to nurses with lower body mass indexes, nurses with a higher body mass indexes had even more negative effects on some physiologic measures such as lower $\mathrm{O}_{2}$ levels and higher heart rate, and worse subjective symptoms such as higher perceived exertion, shortness of breath, thermal discomfort, headaches, lightheadedness, and visual challenges [76].

\section{Other useful measures for gynecologist}

It is clear that masks especially N95 are important but not sufficient. Nowadays, protection measure with activated carbon fiber is increasingly acknowledged [71]. The combination of HEPA filters with activated carbon is commonly called "high efficiency gas adsorption" (HEGA) filters, which successfully prevent surgeons from volatile organic compounds and chemical vapors in surgical smoke [77]. The mask contains an activated carbon layer may provide the surgeon with additional protection [78]. Remarkably, a recent study has demonstrated that the risk of surgical smoke exposure during laparoscopic surgery could be reduced by activated carbon fiber filters [79]. Eighteen chemical components were discovered in the sample collected $20 \mathrm{~min}$ after the electrocautery device used. However, When using the activated carbon fiber filter, known carcinogens including 1,2-dichloroethane, benzene, and ethylbenzene were dramatically reduced by more than $85 \%$ and the risk was extremely eliminated, implying that operating room personnel should pay attention to the risk from surgical smoke and minimize this risk by using activated carbon fiber filter [79]. However, these activated carbon fibers have not been demonstrated in clinical practice, which deserve further investigation before a formal recommendation in gynecology and other surgeons.

In addition, another important precaution is proper and diligent use of a smoke evacuation system with a high efficiency filter. Smoke evacuation has been identified as a feasible and potentially useful way to reduce the surgical smoke [80]. Smoke evacuation is able to capture the smoke generated at the surgical site and remove it to an area away from the surgical team where it can be filtered, which have been shown to be the most effective in limiting exposure to the noxious odor and potential health hazards of electrosurgical and laser plume [81, 82]. The unanimous consensus of all such recognized authorities that the primary measures for protecting people against surgical smoke are local exhaust ventilators, which is composed of wall suction with an in-line particulate filter and smoke evacuator. It filters $99.9995 \%$ of contaminants ranging 0.12 microns or larger in diameter [81]. Consistently, one experiment tested the efficiency of portable smoke evacuation systems and found these filtration reduced surgical smoke up to $99 \%$, however, this accompanied by high sound level, which exceeded recommended threshold limits [83]. Controversially, accumulated evidence has demonstrated the poor efficiency for smoke evacuation system in eliminating volatile organic compounds. One experimental study found that some chemical compounds such as acetaldehyde, acetone, acetonitrile, benzene, hexane, styrene and toluene could be detected but at lower concentrations less than the recommended exposure limits when local exhaust ventilation system is in place [84]. Besides, another group illustrated smoke evacuation system was unable to reduce some chemical compounds containing butadiene and benzene below the permissible exposure limits [38]. Despite recommendations from various professional organizations advocating the use of local exhaust ventilators and respiratory precautions, these measures are not being widely used because of its noise, cost, lack of equipment or repair parts, physician resistance, staff complacency, large and unwieldy local exhaust ventilators devices, and extra personal accommodating devices $[72,76,85]$. A recent web-based survey by Steege et al. [85] examined current surgical smoke practices of local exhaust ventilators and personal protective equipment which include respiratory protection approved by NIOSH. There were 4533 respondents to the survey, $56 \%$ were 
nurses and $21 \%$ were anesthesiologists, the rest were technologists and surgical assistants. The researchers found that only $14 \%$ of respondents reported that local exhaust ventilators were always used during the procedures of electrosurgery, and fewer than half $(47 \%)$ of the facilities used by survey respondents for most laser procedures. Of particular interest to gynecologists, $49 \%$ and $44 \%$ of survey respondents reported that they never had training on the hazards of surgical smoke in laser surgery and electro-surgery, respectively. Many studies demonstrated that better or more adherence of education was needed to raise awareness of potential hazards in surgical smoke and to awaken consciousness of a clear lack of health care personal protective measures, which might be served as a foundation to help inform safety guidelines in electrosurgery for formal gynecologist and obstetrician residents [86, 87]. A team of perioperative nurses and surgeons quantified smoke-evacuator use, assessed staff members' knowledge and presented a multimodal education program in order to improve compliance with policies and procedures for surgical smoke management in the operation room. As a result of a posteducation, this survey showed a $14.6 \%$ increase in surgical smoke-evacuation use which obviously revealed significant improvement in staff members' awareness about reducing surgical smoke in the operation room and helping patients, staff members, and the surgical team to ensure a safe environment [88].

Additionally, disposable smoke evacuation hose is one of the most previous ways used in electrosurgery to reduce surgical smoke [89]. Elimination of surgical smoke via a disposable built-in-filter trocar has been identified as a simple and effective way to reduce chemical compounds such as benzene, toluene, butyraldehyde, ethylbenzene, xylene, styrene, formaldehyde, and propionaldehyde, to some extent [90].

Besides, general room ventilation using a central plume evacuation system connected to several operating suites was also insufficient to effectively capture smoke generated at the surgical site [91]. These central evacuation systems removed the smoke directly to a remote site without using filters, and the captured device connected through tubing to a control panel that controlled the flow rate [81].

In spite of these protections, the existing problems on protections are obvious. On one hand, the outpatient department where most gynecological procedures of treating CIN are performed and operation room have a paucity of protective structures to protect gynecologists, our staff and our patients, there being neither any smoke evacuation system, filter, wall suction, nor a protocol regarding protection against surgical smoke [21]. On the other hand, most surgeons, perioperative personnel, and health care organizations lack a general knowledge regarding the potential health risks associated with exposure to surgical smoke and underuse of equipments that may provide effective protection because of inconvenience and expense [76, 87, 92]. Many surveys revealed that effective engineering controls, such as local exhaust ventilation procedures, were used by fewer than half of the facilities represented by survey respondents for most laser procedures and in very few facilities for most electrosurgery, electrocautery, or diathermy procedures [17, 65]. However, the organisations responsible for protecting the health of the workers in different countries have still not issued formal guidelines for the treatment and removal of the surgical smoke generated in both open and laparoscopic procedures. As gynecologists, we must realize that our decision of rejecting protective measures against surgical smoke will inevitably put not only ourselves but also our staff at risk. Therefore, what we also need is further training and reinforcement of universal precautions to reduce occupational exposures.

\section{Conclusion and perspective}

It is obvious that surgical smoke is dangerous to gynecologists who perform procedures using electrocautery and other heating process to treat CIN. Electrocautery creating particles are small enough to be inhaled through a surgical mask and deposited on the walls bronchioles and alveoli causing pulmonary diseases (List in Figure 1). Several particles contain chemical compounds known as carcinogens and biological substances considered mutagenic and possibly infectious, including malignant cells and viruses (List in Table 1). Further research should be encouraged to quantify the exposure of gynecologists to surgical smoke in the outpatient department. A number of areas not only require more investigation and research to demonstrate the harmful effects of surgical smoke and analyze the contents of the smoke, but also need long-term studies on exposure limits. In spite of doubting about the harmful effects of exposure to surgical smoke, caution should be applied and preventive measures within should be carried. Many guidelines indicate that the most important protective measure against surgical smoke is consistent and correct use of smoke evacuation and surgical mask. But these measures are not consistently implemented, nor are they legally mandated. Therefore, firstly, the diligent use of high-filtration masks in addition to smoke evacuation systems to gynecologists performing surgery is required. 
Secondly, increased knowledge and training of the individual to enhance awareness of health care workers about the hazards of the surgical smoke is recommended. Thirdly, it should have positive perceptions about the attributes of smoke evacuation recommendations and ease of understanding and implementing smoke evacuation system. Lastly, these measures should be consistently implemented and legally mandated soon. Altogether, gynecologists should recognize the danger of surgical plume and request all necessary measures to protect both operating room staff and patients.

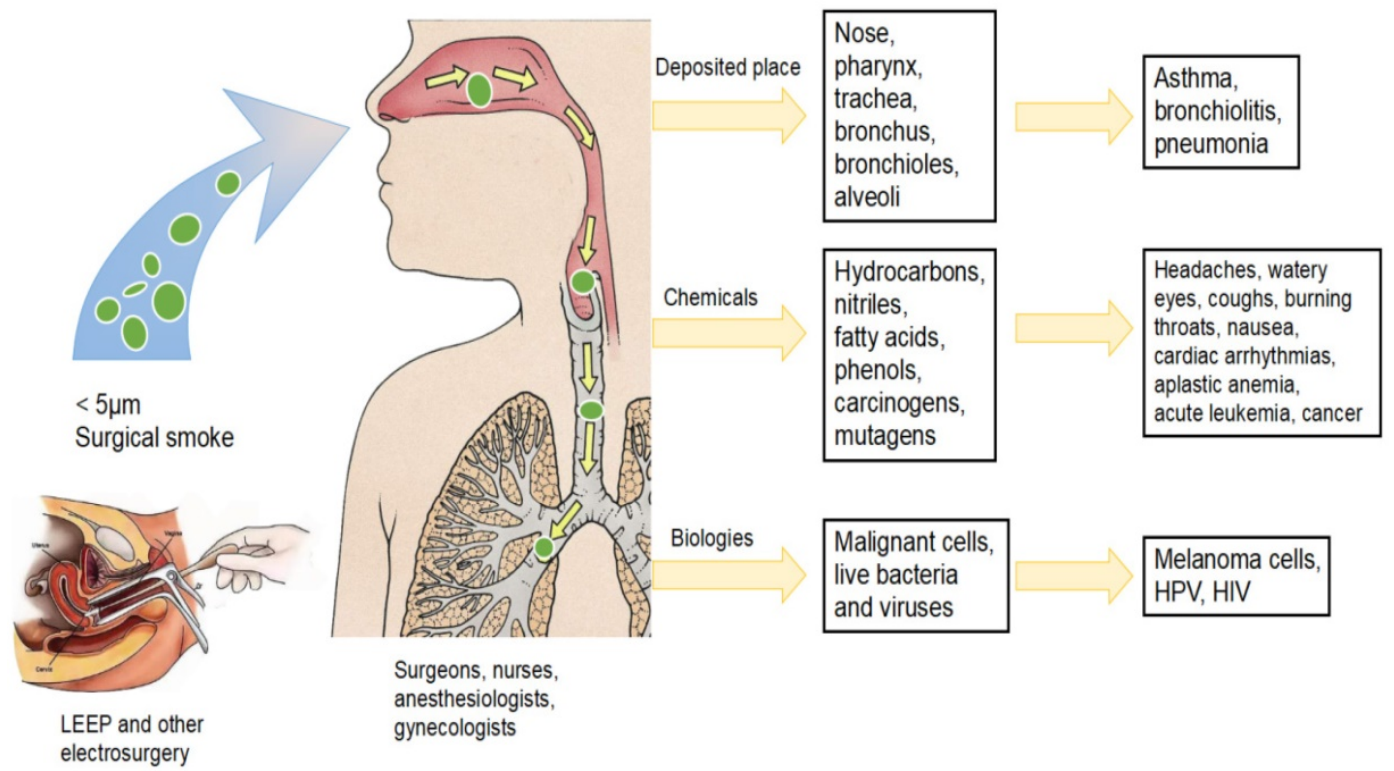

Figure 1: The hazards of surgical smoke produced by electrosurgical procedures to gynecologists. Surgical smoke produced by electrocautery contained particles small enough to be inhaled and deposited on the respiratory tract causing pulmonary diseases. Surgical smoke also poses chemical and biological components causing potential risks for healthcare workers.

Table 1: The various components of surgical smoke produced by electrosurgical procedures

\begin{tabular}{|c|c|c|c|c|}
\hline Year & Surgery type or tissues & Energy device & Components & \\
\hline \multicolumn{5}{|c|}{ Chemical components of surgical smoke } \\
\hline 1998 & porcine liver & $\begin{array}{l}\text { High-frequency } \\
\text { electrocoagulation }\end{array}$ & $\begin{array}{l}\text { 2,3-dihydro indene, 3-butenenitrile, pyrrole, 2-nethyl propanol, 2-methyl furan2,5-dimethyl } \\
\text { furan, } 1 \text { decene, benzonitrile, 6-methyl indole 3-methyl butenal, Methyl pyrazine, } 1 \text { undecene, } \\
\text { ethynyl benzene, 2-propylene nitrile, indole, furfural, hexadecanoic acid, ethyl benzene, } \\
\text { toluene, benzaldehyde, 4-methyl phenol }\end{array}$ & \\
\hline 2007 & $\begin{array}{l}\text { Verrucae, pilonidal sinuses, } \\
\text { abdominal procedures }\end{array}$ & diathermy & $\begin{array}{l}\text { nalkanes, } \mathrm{n} \text {-alkenes and aldehydes as well as toluene, ethyl benzene } \\
\text { and xylene }\end{array}$ & \\
\hline 2007 & abdominal surgery & unipolar diathermy & hydrogen cyanide, acetylene, and 1,3-butadiene & \\
\hline 2010 & $\begin{array}{l}\text { transurethral resection of the } \\
\text { prostate }\end{array}$ & electrosurgical generator & $\begin{array}{l}\text { propylene, allene, isobutylene, 1,3-butadiene, vinyl acetylene, mecaptomethane, ethyl } \\
\text { acetylene, diacetylene, 1-pentene, ethyl alcohol, piperylene, propenylacetylene, 1,4-pentadiene, } \\
\text { cyclopentadiene, acrylonitrile and butyrolactone }\end{array}$ & \\
\hline 2012 & $\begin{array}{l}\text { laparoscopic intraabdominal } \\
\text { surgery }\end{array}$ & $\begin{array}{l}\text { Electrocautery or ultrasonic } \\
\text { scalpels }\end{array}$ & benzene, ethylbenzene, styrene, toluene, heptene, and methylpropene & \\
\hline 2014 & laparoscopic cholecystectomy & electrosurgery & benzene, toluene, xylene, dioxins & \\
\hline 2014 & Dermatologic surgery & $\begin{array}{l}\text { Monoterminal electrodessication } \\
\text { and electrofulguration }\end{array}$ & $\begin{array}{l}\text { 1,3 butadiene, benzene, styrene, propylene, acetonitrile, vinyl acetate, n-heptane, } \\
\text { 1,2-dichloroethane, chloromethane, hexanone, vinyl chloride }\end{array}$ & \\
\hline 2016 & $\begin{array}{l}\text { laparoscopic or robotic } \\
\text { surgery }\end{array}$ & electrosurgery & HBV & \\
\hline 2016 & $\begin{array}{l}\text { Porcine gastric mucosal } \\
\text { ablation }\end{array}$ & electrosurgical probe & $\begin{array}{l}\text { toluene, 2-propyl-1-pentanol, perfluorooctan, propenoic acid, dimetyldodecane, } \\
\text { 2-ethyl-1-hexanol, propylene glycol }\end{array}$ & \\
\hline 2017 & rectal cancer resection & $\begin{array}{l}\text { electrocautery } \\
\text { and ultrasonically activating } \\
\text { scalpel }\end{array}$ & $\begin{array}{l}\text { benzene, toluene, ethylbenzene, xylene, styrene, formaldehyde, acetaldehyde, } \\
\text { propionaldehyde, butyraldehyde, isovaleraldehyde, and valeraldehyde }\end{array}$ & \\
\hline 2018 & human breast tissues & Electrocautery surgical device & $\begin{array}{l}\text { acetaldehyde,a-pinene, benzene, chloroform, } \mathrm{d} \text {-Limonene, ethanol, ethylbenzene, isopropyl } \\
\text { alcohol, m,p-xylene, methyl, methylene, chloride, n-hexane, o-xylene, styrene, toluene }\end{array}$ & \\
\hline 2018 & porcine tissue & electrosurgery & $\begin{array}{l}\text { acetylene, hydrogen cyanide, 1,3-butadiene,benzene,toluene, furfural, styrene, ethyl benzene } \\
\text { and 1-decene }\end{array}$ & \\
\hline 2018 & porcine tissue & electrosurgery & produce different mass concentration and size distribution of smoke particles. & \\
\hline 2018 & $\begin{array}{l}\text { transperitoneal laparoscopic } \\
\text { nephrectomy }\end{array}$ & electrocautery device & $\begin{array}{l}\text { ethanol, 1,2-dichloroethane, benzene, ethylbenzene, and } \\
\text { styrene, acetone, 2-butanone, hexane, n-heptane, toluene, } \\
\text { p-xylene, n-nonane, o-xylene, n-decane, n-undecane, } \\
\text { n-hexadecane, n-tridecane, and n-tetradecane. }\end{array}$ & \\
\hline \multicolumn{5}{|c|}{ Mutagenicity and cytotoxicity of surgical smoke } \\
\hline 1981 & mucous membrane of canine & carbon dioxide laser & mutagenicity of a TA98 strain of Salmonella & \\
\hline
\end{tabular}




\begin{tabular}{|c|c|c|c|c|}
\hline Year & Surgery type or tissues & Energy device & Components & Ref. \\
\hline & tongue & & & \\
\hline 1992 & reduction mammoplazy & electrocautery & mutagenicity of smoke to a TA98 strain of Salmonella & \\
\hline 1998 & porcine liver tissue & electro-surgical hook knife & cytotoxicity & \\
\hline 2018 & human breast tissues & Electrocautery surgical device & cytotoxicity & \\
\hline \multicolumn{5}{|c|}{ Viable malignant cells in surgical smoke } \\
\hline 1999 & mouse melanoma cells & electrocautery & viable melanoma cells & \\
\hline 2009 & mouse melanoma cells. & electrosurgery & viable melanoma cells & \\
\hline 2015 & various tumour cell lines & $\begin{array}{l}\text { electrocautery, radiofrequency } \\
\text { ablation and ultrasonic scalpels }\end{array}$ & viable cells & \\
\hline \multicolumn{5}{|c|}{ Viable bacteria in surgical smoke } \\
\hline 2015 & porcine tissue & electrosurgery & viable bacteria & \\
\hline \multicolumn{5}{|c|}{ Virus in surgical smoke } \\
\hline 1988 & $\begin{array}{l}\text { papilloma virus-infected } \\
\text { verrucae }\end{array}$ & carbon dioxide laser & intact viral HPV DNA & \\
\hline 1989 & human plantar warts & $\begin{array}{l}\text { carbon dioxide laser and } \\
\text { electrocoagulation }\end{array}$ & HPV DNA & \\
\hline 1991 & cultured HIV cells & carbon dioxide laser & HIV proviral DNA & {[} \\
\hline 1994 & $\mathrm{CIN}$ & LEEP & HPV DNA & [ \\
\hline 1999 & $\begin{array}{l}\text { oral polio virus infected } \\
\text { fibroblasts }\end{array}$ & excimer laser & infectious polio virus & \\
\hline 2002 & $\begin{array}{l}\text { bovine papillomavirus- } \\
\text { induced cutaneous } \\
\text { fibropapillomas }\end{array}$ & carbon dioxide laser & bovine papillomavirus DNA & \\
\hline 2011 & genital warts & carbon dioxide laser & HPV DNA & $z$ \\
\hline 2012 & $\begin{array}{l}\text { urethral warts, laryngeal } \\
\text { papilloma }\end{array}$ & carbon dioxide laser & HPV positive & \\
\hline 2016 & $\begin{array}{l}\text { laparoscopic or robotic } \\
\text { surgery }\end{array}$ & electrosurgery & $\mathrm{HBV}$ & \\
\hline 2018 & cervix uteri & LEEP & high-risk HPV & 8 \\
\hline
\end{tabular}

\section{Abbreviations}

BPV: bovine papillomavirus; CIN: cervical intraepithelial neoplasia; HEGA: high efficiency gas adsorption; HEPA: high efficiency particulate air; HPV: human papillomavirus; IARC: International Agency for Research on Cancer; LEEP: loop electrosurgical excisional procedure; NIOSH: National Institute of Occupational Safety and Health; OSHA: Occupational and Safety Health Administration; ppm: parts per million.

\section{Acknowledgements}

This work was supported by the grant from Science and Technology Project of Zhejiang Province (grant number: 2014C33165) and the Key Lab of Wenzhou city-Gynecological Oncology (grant number: ZD201603). The study sponsors had no involvement in the collection, analysis and interpretation of data, or in the writing of the manuscript.

\section{Competing Interests}

The authors have declared that no competing interest exists.

\section{References}

1. Siegel RL, Miller KD, Jemal A. Cancer statistics, 2018. 2018; 68: 7-30.

2. Lopez MS, Baker ES, Maza M, Fontes-Cintra G, Lopez A, Carvajal JM, et al. Cervical cancer prevention and treatment in Latin America. J Surg Oncol. 2017; $115: 615-8$.

3. Sawaya GF, Huchko MJ. Cervical Cancer Screening. Med Clin North Am. 2017: 101: 743-53.

4. Sankaranarayanan R, Thara S, Esmy PO, Basu P. Cervical cancer: screening and therapeutic perspectives. Med Princ Pract. 2008; 17: 351-64.
5. Ramachandran B. Functional association of oestrogen receptors with HPV infection in cervical carcinogenesis. Endocr Relat Cancer. 2017; 24: R99-r108.

6. Li N, Franceschi S, Howell-Jones R, Snijders PJ, Clifford GM. Human papillomavirus type distribution in 30,848 invasive cervical cancers worldwide: Variation by geographical region, histological type and year of publication. Int J Cancer. 2011; 128: 927-35.

7. Mathevet P, Chemali E, Roy M, Dargent D. Long-term outcome of a randomized study comparing three techniques of conization: cold knife, laser, and LEEP. Eur J Obstet Gynecol Reprod Biol. 2003; 106: 214-8.

8. Advincula AP, Wang K. The evolutionary state of electrosurgery: where are we now? Curr Opin Obstet Gynecol. 2008; 20: 353-8.

9. Santesso N, Mustafa RA, Wiercioch W, Kehar R, Gandhi S, Chen Y, et al. Systematic reviews and meta-analyses of benefits and harms of cryotherapy, LEEP, and cold knife conization to treat cervical intraepithelial neoplasia. Int J Gynaecol Obstet. 2016; 132: 266-71.

10. Choi MC, Lee C, Kim SJ. Efficacy and safety of photodynamic therapy for cervical intraepithelial neoplasia: a systemic review. Photodiagnosis Photodyn Ther. 2014; 11: 479-80.

11. Pierce JG, Jr., Bright S. Performance of a colposcopic examination, a loop electrosurgical procedure, and cryotherapy of the cervix. Obstet Gynecol Clin North Am. 2013; 40: 731-57.

12. Hill DS, O'Neill JK, Powell RJ, Oliver DW. Surgical smoke - a health hazard in the operating theatre: a study to quantify exposure and a survey of the use of smoke extractor systems in UK plastic surgery units. J Plast Reconstr Aesthet Surg. 2012; 65: 911-6.

13. Fitzgerald JE, Malik M, Ahmed I. A single-blind controlled study of electrocautery and ultrasonic scalpel smoke plumes in laparoscopic surgery. Surgical endoscopy. 2012; 26: 337-42.

14. Mowbray N, Ansell J, Warren N, Wall P, Torkington J. Is surgical smoke harmful to theater staff? a systematic review. Surgical endoscopy. 2013; 27: 3100-7.

15. Pollock L. Hazards of Electrosurgical Smoke. Perioperative Nursing Clinics. 2007; 2: 127-38.

16. Waddell AW. Cultivating quality: implementing surgical smoke evacuation in the operating room. Am J Nurs. 2010; 110: 54-8.

17. Ulmer BC. The hazards of surgical smoke. Aorn j. 2008; 87: 721-34; quiz 35-8.

18. Barrett WL, Garber SM. Surgical smoke: a review of the literature. Is this just a lot of hot air? Surgical endoscopy. 2003; 17: 979-87.

19. Weld KJ, Dryer S, Ames CD, Cho K, Hogan C, Lee M, et al. Analysis of surgical smoke produced by various energy-based instruments and effect on laparoscopic visibility. J Endourol. 2007; 21: 347-51.

20. Chung YJ, Lee SK, Han SH, Zhao C, Kim MK, Park SC, et al. Harmful gases including carcinogens produced during transurethral resection of the prostate and vaporization. Int J Urol. 2010; 17: 944-9.

21. Ilce A, Yuzden GE, Yavuz van Giersbergen M. The examination of problems experienced by nurses and doctors associated with exposure to surgical smoke and the necessary precautions. J Clin Nurs. 2017; 26: 1555-61.

22. Baggish MS, Poiesz BJ, Joret D, Williamson P, Refai A. Presence of human immunodeficiency virus DNA in laser smoke. Lasers Surg Med. 1991; 11: 197-203. 
23. Sood AK, Bahrani-Mostafavi Z, Stoerker J, Stone IK. Human papillomavirus DNA in LEEP plume. Infectious diseases in obstetrics and gynecology. 1994; 2: 167-70.

24. Fletcher JN, Mew D, DesCoteaux JG. Dissemination of melanoma cells within electrocautery plume. Am J Surg. 1999; 178: 57-9.

25. Choi SH, Kwon TG, Chung SK, Kim TH. Surgical smoke may be a biohazard to surgeons performing laparoscopic surgery. Surgical endoscopy. 2014; 28: 2374-80.

26. Lewin JM, Brauer JA, Ostad A. Surgical smoke and the dermatologist. J Am Acad Dermatol. 2011; 65: 636-41.

27. Sanderson C. Surgical smoke. J Perioper Pract. 2012; 22: 122-8.

28. Okoshi K, Kobayashi K, Kinoshita K, Tomizawa Y, Hasegawa S, Sakai Y. Health risks associated with exposure to surgical smoke for surgeons and operation room personnel. Surg Today. 2015; 45: 957-65.

29. Karjalainen M, Kontunen A, Saari S, Ronkko T, Lekkala J, Roine A, et al. The characterization of surgical smoke from various tissues and its implications for occupational safety. PloS one. 2018; 13: e0195274.

30. Marsh S. The smoke factor: things you should know. J Perioper Pract. 2012; 22: 91-4.

31. Bree K, Barnhill S, Rundell W. The Dangers of Electrosurgical Smoke to Operating Room Personnel: A Review. Workplace Health Saf. 2017; 65: 517-26.

32. Baggish MS, Baltoyannis P, Sze E. Protection of the rat lung from the harmful effects of laser smoke. Lasers Surg Med. 1988; 8: 248-53.

33. Baggish MS, Elbakry M. The effects of laser smoke on the lungs of rats. Am J Obstet Gynecol. 1987; 156: 1260-5.

34. Gates MA, Feskanich D, Speizer FE, Hankinson SE. Operating room nursing and lung cancer risk in a cohort of female registered nurses. Scand J Work Environ Health. 2007; 33: 140-7.

35. Ball K. Compliance with surgical smoke evacuation guidelines: implications for practice. Aorn j. 2010; 92: 142-9.

36. Pierce JS, Lacey SE, Lippert JF, Lopez R, Franke JE. Laser-generated air contaminants from medical laser applications: a state-of-the-science review of exposure characterization, health effects, and control. J Occup Environ Hyg. 2011; 8: 447-66.

37. Al Sahaf OS, Vega-Carrascal I, Cunningham FO, McGrath JP, Bloomfield FJ. Chemical composition of smoke produced by high-frequency electrosurgery. Irish journal of medical science. 2007; 176: 229-32

38. Kocher GI, Sesia SB, Lopez-Hilfiker F, Schmid RA. Surgical smoke: still an underestimated health hazard in the operating theatre. Eur J Cardiothorac Surg. 2019; 55: 626-31.

39. Sisler JD, Shaffer J, Soo JC, LeBouf RF, Harper M, Qian Y, et al. In vitro toxicological evaluation of surgical smoke from human tissue. J Occup Med Toxicol. 2018; 13: 12

40. Wu JS, Luttmann DR, Meininger TA, Soper NJ. Production and systemic absorption of toxic byproducts of tissue combustion during laparoscopic surgery. Surgical endoscopy. 1997; 11: 1075-9.

41. Sagar PM, Meagher A, Sobczak S, Wolff BG. Chemical composition and potential hazards of electrocautery smoke. Br J Surg. 1996; 83: 1792.

42. Dobrogowski M, Wesolowski W, Kucharska M, Sapota A, Pomorski LS. Chemical composition of surgical smoke formed in the abdominal cavity during laparoscopic cholecystectomy--assessment of the risk to the patient. Int J Occup Med Environ Health. 2014; 27: 314-25.

43. Wild CP. International Agency for Research on Cancer in Encyclopedia of Toxicology (Third Edition). Academic Press: Oxford. 2014: 1067-9.

44. Oganesyan G, Eimpunth S, Kim SS, Jiang SI. Surgical smoke in dermatologic surgery. Dermatol Surg. 2014; 40: 1373-7.

45. Tomita Y, Mihashi S, Nagata K, Ueda S, Fujiki M, Hirano M, et al. Mutagenicity of smoke condensates induced by CO2-laser irradiation and electrocauterization. Mutat Res. 1981; 89: 145-9.

46. Gatti JE, Bryant CJ, Noone RB, Murphy JB. The mutagenicity of electrocautery smoke. Plast Reconstr Surg. 1992; 89: 781-4; discussion 5-6.

47. Hensman C, Newman EL, Shimi SM, Cuschieri A. Cytotoxicity of electro-surgical smoke produced in an anoxic environment. Am J Surg. 1998; 175: $240-1$

48. Lindsey C, Hutchinson M, Mellor G. The nature and hazards of diathermy plumes: a review. Aorn j. 2015; 101: 428-42.

49. Ikramuddin S, Lucus J, Ellison EC, Schirmer WJ, Melvin WS. Detection of aerosolized cells during carbon dioxide laparoscopy. J Gastrointest Surg. 1998; 2: 580-3; discussion 4.

50. In SM, Park DY, Sohn IK, Kim CH, Lim HL, Hong SA, et al. Experimental study of the potential hazards of surgical smoke from powered instruments. Br J Surg. 2015; 102: 1581-6.

51. Schultz L. Can Efficient Smoke Evacuation Limit Aerosolization of Bacteria? Aorn j. 2015; 102: 7-14.

52. Weyandt GH, Tollmann F, Kristen P, Weissbrich B. Low risk of contamination with human papilloma virus during treatment of condylomata acuminata with multilayer argon plasma coagulation and $\mathrm{CO}(2)$ laser ablation. Arch Dermatol Res. 2011; 303: 141-4.

53. Manson LT, Damrose EJ. Does exposure to laser plume place the surgeon at high risk for acquiring clinical human papillomavirus infection? Laryngoscope. 2013; 123: 1319-20.

54. Garden JM, O'Banion MK, Shelnitz LS, Pinski KS, Bakus AD, Reichmann ME, et al. Papillomavirus in the vapor of carbon dioxide laser-treated verrucae. Jama. 1988; 259: 1199-202.
55. Sawchuk WS, Weber PJ, Lowy DR, Dzubow LM. Infectious papillomavirus in the vapor of warts treated with carbon dioxide laser or electrocoagulation: detection and protection. J Am Acad Dermatol. 1989; 21: 41-9.

56. Garden JM, O'Banion MK, Bakus AD, Olson C. Viral disease transmitted by laser-generated plume (aerosol). Arch Dermatol. 2002; 138: 1303-7.

57. Ilmarinen T, Auvinen E, Hiltunen-Back E, Ranki A, Aaltonen LM, Pitkaranta A. Transmission of human papillomavirus DNA from patient to surgical masks, gloves and oral mucosa of medical personnel during treatment of laryngeal papillomas and genital warts. Eur Arch Otorhinolaryngol. 2012; 269: 2367-71.

58. Neumann K, Cavalar M, Rody A, Friemert L, Beyer DA. Is surgical plume developing during routine LEEPs contaminated with high-risk HPV? A pilot series of experiments. Arch Gynecol Obstet. 2018; 297: 421-4.

59. Hallmo $P$, Naess O. Laryngeal papillomatosis with human papillomavirus DNA contracted by a laser surgeon. Eur Arch Otorhinolaryngol. 1991; 248: 425-7.

60. Calero L, Brusis T. [Laryngeal papillomatosis - first recognition in Germany as an occupational disease in an operating room nurse]. Laryngorhinootologie. 2003; 82: 790-3

61. Rioux M, Garland A, Webster D, Reardon E. HPV positive tonsillar cancer in two laser surgeons: case reports. J Otolaryngol Head Neck Surg. 2013; 42: 54

62. Goon PKC, Goon PKY, Tan EKH, Crawford RAF, Levell NJ, Sudhoff H. Virus-Induced Cancers of the Skin and Mucosa: Are We Dealing with "Smoking Guns" or "Smoke and Mirrors" in the Operating Theatre? Dermatology and therapy. 2017; 7: 249-54

63. Taravella MJ, Weinberg A, May M, Stepp P. Live virus survives excimer laser ablation. Ophthalmology. 1999; 106: 1498-9.

64. Kwak HD, Kim SH, Seo YS, Song KJ. Detecting hepatitis B virus in surgical smoke emitted during laparoscopic surgery. Occup Environ Med. 2016; 73: 857-63.

65. Coleman, Scott A. Protecting yourself against surgical smoke. Or Nurse. 2014; 8: 40-6.

66. Jamal S, Hassan M, Farooqi M, Ali S. Surgical Smoke-Concern for Both Doctors and Patients. Indian J Surg. 2015; 77: 1494-5.

67. Oberg T, Brosseau LM. Surgical mask filter and fit performance. Am J Infect Control. 2008; 36: 276-82.

68. Makison Booth C, Clayton M, Crook B, Gawn JM. Effectiveness of surgical masks against influenza bioaerosols. J Hosp Infect. 2013; 84: 22-6.

69. Benson SM, Novak DA, Ogg MJ. Proper use of surgical n95 respirators and surgical masks in the OR. Aorn j. 2013; 97: 457-67; quiz 68-70.

70. Fan JK, Chan FS, Chu KM. Surgical smoke. Asian J Surg. 2009; 32: 253-7.

71. Georgesen C, Lipner SR. Surgical smoke: Risk assessment and mitigation strategies. J Am Acad Dermatol. 2018; 79: 746-55.

72. Edwards BE, Reiman RE. Comparison of current and past surgical smoke control practices. Aorn j. 2012; 95: 337-50.

73. Gao S, Koehler RH, Yermakov M, Grinshpun SA. Performance of Facepiece Respirators and Surgical Masks Against Surgical Smoke: Simulated Workplace Protection Factor Study. Ann Occup Hyg. 2016; 60: 608-18.

74. Lu W, Zhu XC, Zhang XY, Chen YT, Chen WH. [Respiratory protection provided by $\mathrm{N} 95$ filtering facepiece respirators and disposable medicine masks against airborne bacteria in different working environments]. Zhonghua Lao Dong Wei Sheng Zhi Ye Bing Za Zhi. 2016; 34: 643-6.

75. Offeddu V, Yung CF, Low MSF, Tam CC. Effectiveness of Masks and Respirators Against Respiratory Infections in Healthcare Workers: A Systematic Review and Meta-Analysis. Clin Infect Dis. 2017; 65: 1934-42.

76. Rebmann T, Carrico R, Wang J. Physiologic and other effects and compliance with long-term respirator use among medical intensive care unit nurses. Am J Infect Control. 2013; 41: 1218-23.

77. Wambier CG, Lee KC, Oliveira PB, Wambier SPF, Beltrame FL. Comment on "Surgical smoke: Risk assessment and mitigation strategies" and chemical adsorption by activated carbon N95 masks. J Am Acad Dermatol. 2019; 80: e79-e80.

78. Georgesen C, Lipner SR. Reply to: "Comment on 'Surgical smoke: Risk assessment and mitigation strategies' and chemical adsorption by activated carbon N95 masks". J Am Acad Dermatol. 2019; 80: e81.

79. Choi SH, Choi DH, Kang DH, Ha YS, Lee JN, Kim BS, et al. Activated carbon fiber filters could reduce the risk of surgical smoke exposure during laparoscopic surgery: application of volatile organic compounds. Surg Endosc. 2018; 32: 4290-8

80. Takahashi H, Hirota M, Takahashi T, Yamasaki M, Miyazaki Y, Makino T, et al. Simultaneous automatic insuf $\mathrm{fl}$ ation and smoke-evacuation system in flexible gastrointestinal endoscopy. Endoscopy. 2016; 48: 579-83.

81. Schultz L. An analysis of surgical smoke plume components, capture, and evacuation. Aorn j. 2014; 99: 289-98

82. Bigony L. Risks associated with exposure to surgical smoke plume: a review of the literature. Aorn j. 2007; 86: 1013-20; quiz 21-4.

83. Seipp HM, Steffens T, Weigold J, Lahmer A, Maier-Hasselmann A, Herzog T, et al. Efficiencies and noise levels of portable surgical smoke evacuation systems. J Occup Environ Hyg. 2018; 15: 773-81.

84. Lee T, Soo JC, LeBouf RF, Burns D, Schwegler-Berry D, Kashon M, et al. Surgical smoke control with local exhaust ventilation: Experimental study. J Occup Environ Hyg. 2018; 15: 341-50.

85. Steege AL, Boiano JM, Sweeney MH. Secondhand smoke in the operating room? Precautionary practices lacking for surgical smoke. Am J Ind Med. 2016; 59: 1020-31. 
86. Nichol K, McGeer A, Bigelow P, O'Brien-Pallas L, Scott J, Holness DL. Behind the mask: Determinants of nurse's adherence to facial protective equipment. Am J Infect Control. 2013; 41: 8-13.

87. Chapman LW, Korta DZ, Lee PK, Linden KG. Awareness of Surgical Smoke Risks and Assessment of Safety Practices During Electrosurgery Among US Dermatology Residents. JAMA Dermatol. 2017; 153: 467-8.

88. Chavis S, Wagner V, Becker M, Bowerman MI, Jamias MS. Clearing the Air About Surgical Smoke: An Education Program. Aorn j. 2016; 103: 289-96.

89. Neill BC, Golda NJ. Smoke-evacuating cautery pencils for dermatologic surgery. J Am Acad Dermatol. 2017; 77: e137-e8.

90. Hahn KY, Kang DW, Azman ZAM, Kim SY, Kim SH. Removal of Hazardous Surgical Smoke Using a Built-in-Filter Trocar: A Study in Laparoscopic Rectal Resection. Surg Laparosc Endosc Percutan Tech. 2017; 27: 341-5.

91. Springer R. Surgical smoke. Plast Surg Nurs. 2007; 27: 221-2.

92. Edwards BE, Reiman RE. Results of a survey on current surgical smoke control practices. Aorn j. 2008; 87: 739-49.

93. Hensman C, Baty D, Willis RG, Cuschieri A. Chemical composition of smoke produced by high-frequency electrosurgery in a closed gaseous environment. An in vitro study. Surgical endoscopy. 1998; 12: 1017-9.

94. Moot AR, Ledingham KM, Wilson PF, Senthilmohan ST, Lewis DR, Roake J, et al. Composition of volatile organic compounds in diathermy plume as detected by selected ion flow tube mass spectrometry. ANZ journal of surgery. 2007; 77: 20-3. 